\title{
Socio-hydrologic drivers of the pendulum swing between agricultural development and environmental health: a case study from Murrumbidgee River basin, Australia
}

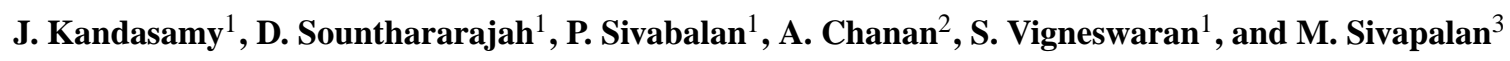 \\ ${ }^{1}$ University of Technology Sydney, Sydney, Australia \\ ${ }^{2}$ State Water Corporation of NSW, Sydney, Australia \\ ${ }^{3}$ University of Illinois at Urbana-Champaign, Urbana, IL, USA
}

Correspondence to: J. Kandasamy (jaya.kandasamy@uts.edu.au)

Received: 21 May 2013 - Published in Hydrol. Earth Syst. Sci. Discuss.: 5 June 2013

Revised: 21 January 2014 - Accepted: 6 February 2014 - Published: 13 March 2014

\begin{abstract}
This paper presents a case study centred on the Murrumbidgee River basin in eastern Australia. It illustrates the dynamics of the balance between water extraction and use for food production, and efforts to mitigate and reverse consequent degradation of the riparian environment. In particular, the paper traces the history of a pendulum swing between an exclusive focus on agricultural development and food production in the initial stages and its attendant socioeconomic benefits, followed by the gradual realization of the adverse environmental impacts, subsequent efforts to mitigate these with the use of remedial measures, and ultimately concerted efforts and externally imposed solutions to restore environmental health and ecosystem services. The 100-year history of development within the Murrumbidgee is divided into four eras, each underpinned by the dominance of different values and norms and turning points characterized by their changes. The various stages of development can be characterized by the dominance, in turn, of infrastructure systems, policy frameworks, economic instruments, and technological solutions. The paper argues that, to avoid these costly pendulum swings, management needs to be underpinned by long-term coupled socio-hydrologic system models that explicitly include the two-way coupling between human and hydrological systems, including the slow evolution of human values and norms relating to water and the environment. Such coupled human-water system models can provide insights into dominant controls of the trajectory of their co-evolution in a given system, and can also be used to interpret patterns of co-evolution of such coupled systems in
\end{abstract}

different places across gradients of climatic, socio-economic and socio-cultural conditions, and in this way to help develop generalizable understanding.

\section{Introduction}

Water resource management decisions we make, be they infrastructure- or policy related, produce positive or negative impacts that in many cases can last a long time. Therefore, in the emergent Anthropocene, given the growing demand for water resources to satisfy increasing human populations, there is an urgent need for water resources management decisions to be based on predictions over long (decadal to century) timescales. In order to make predictions of future water resources, we need reasonable models of how future human societies will demand, use and supply water. The difficulty in predicting this is compounded by the fact that humans do not normally organize themselves solely to optimize access to or utilize water resources. The reality is that humans often use and/or manage water resources so as to maximize the overall well-being of members of society. Human well-being can be framed in several ways, depending on local circumstances. It could be drinking water supply to cities, or water for food or hydropower production; it could be protection from floods or the maintenance of water quality or ecosystem health.

Consequently, hydrologic predictions over long timescales cannot escape the twin problem of predicting how human societies evolve with respect to how they perceive water use 
in its many manifestations. The challenge this poses for prediction is clearly illustrated in the case study from Australia presented in this paper, where hydrology is governed by the physical (natural and human-induced), socio-economic and institutional structures but these are in turn shaped by changing values and norms of the population regarding water and the environment.

Australia has had a long history of promoting agricultural development through harnessing its water resources, making it a defining feature of the country's social identity. Agricultural development has brought significant economic benefits to Australian society, contributing to national economic growth, regional development and secure food supplies. However, it is becoming clear that these societal and economic benefits have been achieved at significant environmental cost, through mounting pressure on, and degradation of, the riparian environment, impairment of water quality and reduction of biodiversity. These problems have been exacerbated by recent prolonged droughts and increased demand for water, food and other amenities characteristic to a growing population, posing major challenges for water management.

A vivid example of these water management challenges is the crisis situation that has unfolded in recent times in the Murray-Darling Basin (MDB) in eastern Australia (Roderick, 2011). The crisis over water use in the MDB revolved around the competition for water resources between humans and ecosystems. The balance of water utilization within the MDB remained strongly in favour of water use for irrigated agriculture for 75 years. The degradation of the environment resulting from the long period of intensive irrigated agriculture, and failure of several efforts to mitigate their negative environmental impacts contributed to a change of community attitudes, which in the end forced the hand of the government to act in a decisive manner and impose a solution to achieve environmental outcomes (MDBA, 2010). Consequently, the balance has now decisively shifted in favour of the environment, evidenced not only by the relative amounts of water allocated for human and environmental uses, but also in water infrastructure investments and changes to human settlement patterns. However, the proposed cutbacks to water allocation for irrigation, as part of the government-imposed solution to alleviate environmental degradation, threaten the economic livelihood of rural Australia, causing a public and heated debate between farmers and regulators.

Gleick and Palaniappan (2010) describe the situation that prevails in the MDB in terms of "peak ecological water", which they define as the "point beyond which the total costs of ecological disruptions and damages exceed the total value provided by human use of that water". In coming decades, as human populations and economies grow further, it is likely that such problems could become increasingly prevalent in other parts of the world as well. Finding the delicate balance between competing water needs of humans and ecosys- tems in the management of water resources is becoming an urgent need worldwide (Scholz and Stiftel, 2005; Richter, 2013; Sivapalan, 2011).

The rapid changes that the water cycle and the environment are likely to experience as a result of natural climatic variability and increasing anthropogenic changes require that prediction and management frameworks must account for not only the effects of climate variability and human interferences on hydrologic variability, but also how hydrologic variability and associated environmental changes and possible degradation in turn influence the human responses and behaviour changes. In the past these feedbacks were not included in the hydrological predictions that underpinned traditional integrated water resource management (IWRM). The impact of human-induced change using IWRM is usually assessed with a scenario-based analysis which typically does not involve feedbacks, co-evolution and resulting non-stationarity in system behaviour. With the increasing severity of human impacts, it is becoming evident that incorporating two-way feedbacks is essential for a better understanding of coupled human-natural systems (Montanari et al., 2013). Recently, Sivapalan et al. (2012) have proposed a socio-hydrologic framework that permits the study of coupled human-water system dynamics, including inherent bi-directional feedbacks between the two sub-systems. Indeed, socio-hydrology accounts for a balancing of economic and environmental well-being, with consideration for changing social norms or community attitudes in respect of the environment.

This paper will present the history of how the water crisis unfolded in the MDB, and a socio-hydrologic interpretation of the co-evolutionary dynamics of the coupled humanwater system. In particular, it will chart the history of water utilization within the MDB, but with a particular focus on the Murrumbidgee, a major sub-catchment of the MDB and the most significantly impacted. The paper will highlight the dynamics of human-water interactions that resulted in a "pendulum swing" or turn-around in the balance point in water allocations between humans and ecosystems, and the natural and societal factors that contributed to this pendulum swing. Understanding the causes of the pendulum swing in the Murrumbidgee River basin within a quantitative and universal socio-hydrologic framework has potential to provide useful lessons for other river basins globally that are undergoing similar development and tensions between competing stakeholders.

\section{Location of study, data and methods}

The Murray-Darling Basin (MDB) is Australia's most iconic river system and is defined by the catchment areas of the Murray and Darling rivers and their many tributaries (Fig. 1). The MDB extends over one million $\mathrm{km}^{2}$ of south-east Australia, representing approximately one-seventh of Australia's 


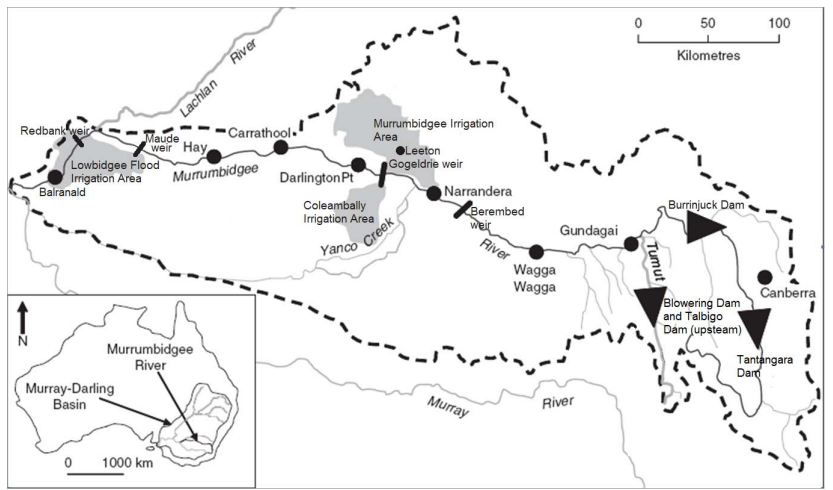

Fig. 1. Murrumbidgee Catchment within the Murray-Darling Basin (adapted from: Frazier and Page, 2006). The Murrumbidgee Irrigation Area incorporates the the Yanco Irrigation Area, Mirrool Irrigation Area, Wah Wah Irrigation District, Benerembah Irrigation District, and Tabbita Irrigation District. In the figure dots or filled circles refer to towns, filled triangles to dams and bars to weirs.

landmass. The MDB displays a varied landscape, from semi-arid ephemeral river systems in the north to highly regulated river systems in the south. It supports a great number of plants, animals and ecosystems that are both nationally and internationally significant, including 95 inundationdependent fauna species, and more than half the nation's native fish species. The economic success of the MDB is a direct result of historical efforts by MDB States (New South Wales (NSW), Queensland, Victoria and South Australia) and the Commonwealth Government to harness its water resources for agriculture. This is exemplified by the fact that it supplies some $40 \%$ of Australia's food needs and supports a resident population of 2.1 million people. In 2006 more than 920000 people were employed across the MDB within the agricultural industry, contributing an average of AUD 15 billion per annum to the Australian economy (MDBA, 2010).

The Murrumbidgee River basin, one of the largest subbasins within MDB (Fig. 1), is located in the south-east of the MDB, and has a population of over 540000 . Although only representing approximately $8 \%$ of the MDB's area, the Murrumbidgee Basin accounts for $22 \%$ of the surface water diverted for irrigation and urban use. It contributes $25 \%$ of NSW's fruit and vegetable production, $42 \%$ of NSW's grapes and half of Australia's rice production. Agricultural production within the Murrumbidgee is valued at over AUD 1.9 billion annually (Murrumbidgee CMA, 2012, 2006) or $0.2 \%$ of Australia's GDP.

One of the goals of this paper is to trace the history of the "pendulum swing", commencing with an exclusive focus on agricultural development and food production and their consequent socio-economic benefits, followed by the gradual realization of the adverse environmental impacts, efforts to mitigate these with the use of remedial measures, and finally concerted efforts and externally imposed solutions to restore environmental health and ecosystem services. This goal is sought through a critical review of the substantial literature that exists in government and consultants' reports, and additional new quantitative trend analyses of several hydrological and social variables that contribute to or reflect the pendulum swing.

The trend analyses reported in this paper were carried out on primary data sourced from several Australian Government agencies: NSW State Water Corporation, Australian Bureau of Statistics, and the Australian Department of Sustainability, Environment, Water, Population and Communities. The trends in the data of water use, agricultural production, and environmental flows are correlated with the history of development of agriculture, government policy and investment, social issues, and environment conditions within the Murrumbidgee Catchment. The results of the trend analyses are used to support or confirm the narratives presented in previously published (including government) reports. Guided by these trends and narratives, a secondary goal of the exercise is the development of a perceptual model of the coupled socio-hydrologic system operating within the Murrumbidgee Basin, framing it in terms of the two-way coupling of social and hydrologic systems (e.g. Cai et al., 2002). Furthermore, a perceptual model that has wider applicability across climatic and socio-economic gradients is also sought through generalizing the drivers, and interactions and feedbacks, in a manner that has wider applicability. This also exploits the similarities based on anecdotal and published evidence between basins in different parts of the world (e.g. Murrumbidgee vs. Sacramento River basin in California, USA, and Tarim Basin in western China), while acknowledging the differences that do exist (Srinivasan et al., 2012; Liu et al., 2013).

\section{How the pendulum swung in the Murrumbidgee}

\subsection{Murrumbidgee Basin as human-water system}

The Murrumbidgee River basin is a highly human impacted and managed system. Over the past 100 years, the basin has been almost entirely transformed through the introduction of human-built infrastructure (e.g. dams and weirs) to support expansion of irrigated agriculture. The irrigation infrastructure as well as irrigation schemes add to or overlie landscape features associated with natural river basins, such as hillslopes, wetlands, riparian areas and river networks. The human-induced structures have altered the flow dynamics that normally result from external climatic drivers (i.e. precipitation). This has caused the diversion of much water that would have flowed down the river network to the ocean and periodically inundated precious wetlands and riparian areas, instead of targeted irrigation areas. In these areas, water is utilized by agricultural crops for increasing crop yield, eventually returning to the atmosphere via transpiration.

The above description refers only to the hydrologic dynamics in this human-managed landscape. However, in the 


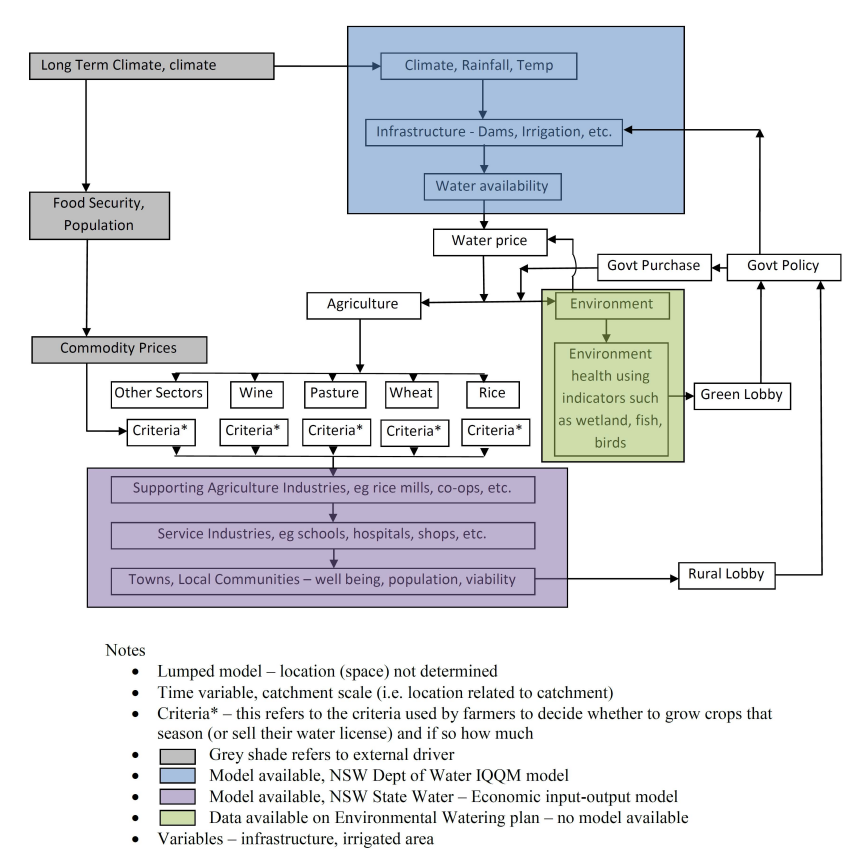

Fig. 2. Conceptual model for catchment-scale competition for water utilization between agriculture and environment using the sociohydrology approach.

intermediate term, these dynamics are accompanied by other slower dynamics relating to human decisions concerning areas to be put under irrigation, types of crops to be grown, and when and how much to irrigate. How much land is put to agriculture and the choice of crops are normally decentralized decisions that depend on externalities such as commodity prices, availability (i.e. in the dams) and price of water for irrigation, as well as the climate itself (which determines the demand for irrigation). The volume of water stored in dams and their price depend upon the climate over the previous few years, but increasingly also upon how much water may be allocated to the environment in the form of environmental flows. The allocation of water between agriculture and environment is governed by economic benefits of agriculture and the value placed by society on the environment, including water quality and biodiversity. This competition for water between irrigated agriculture and the environment is mediated in the political arena, on the basis of arguments by the rural lobby (acting on behalf of the irrigators) and green lobby (acting on behalf of the environment). The relative strengths of the green and rural lobbies influence government decisions to purchase water rights from the irrigators, and to support the environment through construction of specialized infrastructure geared towards protecting or enhancing the environment.

Figure 2 is a schematic describing the organization of the coupled human-water system specific to Murrumbidgee, along the lines presented above. Clearly, as seen in Fig. 2, human management of the water system over the last 100 years has resulted in a system of enormous (apparent) complexity, spanning physical infrastructure and the economic, policy and legal frameworks governing water availability, use and pricing. In fact, the system is even more complex than is shown in Fig. 2 due to the fact that the human-water interactions and feedbacks occur in a distributed manner within the basin at a range of space and timescales. The complexity of the linkages shown in Fig. 2, which is the end result of a century of human management of the system, is a far cry from what might have existed when agriculture first developed within the Murrumbidgee 100 years ago. This system had evolved from a simpler agriculture system practiced by Aboriginal peoples and then the early settlers (see Sect. 3.1). During these times human impact on the hydrological and eco-environmental system was limited to local water extraction. In Fig. 2 this is depicted by a balance of water usage between agriculture and the environment without nearly any of the other influences being relevant. An understanding of how this complexity grew over time to become what it is today can inform the development of models of coupled humanwater systems, and will give us the insights and a predictive capability that may help to avoid similar management crises from developing in river basins in other parts of the world.

\subsection{Pendulum swing in water utilization}

Published studies have documented how the balance in water utilization between agriculture and the environment, and associated infrastructure development, have evolved over the last 100 years. A synthesis of previously published reports and the results of new quantitative analyses carried out for this study resulted in the evolutionary history that is presented schematically in Fig. 3. The data underpinning the trends depicted schematically in Fig. 3 are presented in Fig. 4. Major policies and initiatives that facilitated developments in this period are summarized in Table 1. The history is framed in terms of the relative emphasis placed on agricultural development and environmental health, divided into four distinct eras:

- Era 1: circa 1900-1980 - development of irrigation and associated infrastructure;

- Era 2: circa 1960-1990 - gradual appearance of environmental degradation;

- Era 3: circa 1990-2007 - awareness of broader environmental impacts and a focus on consensus strategies and policies to achieve sustainable management;

- Era 4: circa 2007 to present - failure of the consensus model and emergence of a directed government interventionist strategy to achieve environmentally sustainable outcomes.

We next present a summary of the results of the synthesis presented in Figs. 3 and 4, followed subsequently by a detailed 


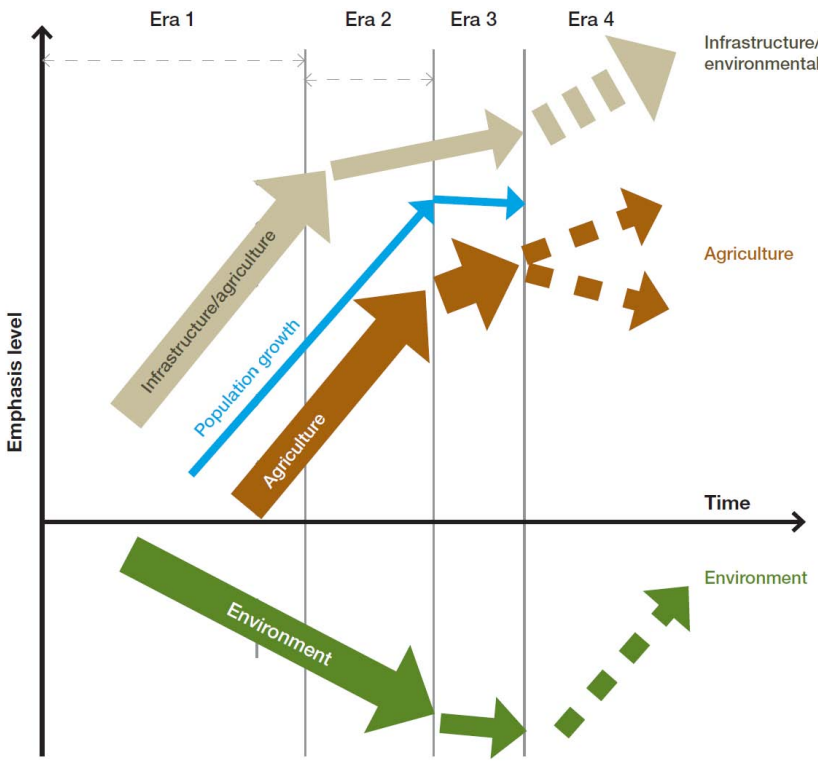

Fig. 3. The change in infrastructure, the environment, population and agriculture production in the Murrumbidgee through four eras: Era 1 (1900-1960) - the development of irrigation and associated infrastructure; Era 2 (1960-1990) - agradual appreciation of realization of environmental degradation; Era 3 (1990-2007) - awareness of broader environmental impacts and a focus on consensus strategies and policies to achieve integrated and sustainable management; Era 4 (2007-present) - accepting the failure of the consensus model, with the emergence of a directed Commonwealth Government strategy to achieve environmental sustainable outcomes. Emphasis level used in relation to the vertical axis refers to the degree of increase in the parameters described in the figure (agriculture, population, infrastructure, and environment).

description of how and why these happened, including substantiation by the results of quantitative analyses.

Era 1 saw rapid growth of agriculture infrastructure. The growth in human population and agricultural production followed into Era 2. By the end of Era 2 there was increasing awareness of environmental degradation, but these were addressed through ad hoc solutions. Era 3 saw growing appreciation of broader environmental impacts, and led to the exploration of a range of strategies aimed at their mitigation. As environmental degradation continued unabated, Era 4 saw a major switch in emphasis towards environmental health, with both agricultural production and population growth showing sharp reverses, and increased investment in infrastructure aimed at the enhancement of the environment. The switch from the earlier emphasis on agricultural development to a new emphasis on environmental health, shown in Fig. 3, is an example of a pendulum swing from era to era. The term "pendulum swing" in this case refers to a shift in the balance in water utilization between agricultural development and environmental health (Fig. 2). An understanding of how this pendulum swing occurred and the factors that contributed to it can assist towards the development of a new coupled socio- hydrology model that encapsulates a deep understanding of these factors and might guide system managers to develop policies resulting in a more sustainable development trajectory (see Sect. 4). In the next few sub-sections, we present a more detailed description of the changes that happened in the Murrumbidgee River basin over the past 100 years.

\subsubsection{Era 1 (1900-1980): expansion of agriculture and associated irrigation infrastructure}

It is well documented that Aboriginals lived sustainably in the Australian landscape for tens of thousands of years (Humphries, 2007). The situation changed with the settling of Europeans, who displaced the Aboriginals, cleared forests and native grasses, introduced new grasses, cereal crops, cattle and sheep. They built farm dams and introduced irrigation schemes for intensive cultivation and more productive use of lands on the floodplains. These efforts were supported by government investment in irrigation infrastructure and government coordination in the sharing of waters.

Government investment in, and coordination of, irrigated agriculture was motivated by several factors. Firstly, the development of agriculture was representative of the preeminence of agriculture in the Australian economy in the early to mid-20th century. The Murrumbidgee, along with the MDB, became Australia's food bowl, growing and processing a significant fraction of all fruits and vegetables. For example, during the first half of the 20th century, agriculture accounted for up to $35 \%$ of the share of the Australian economy and 70-80\% of Australia's exports (Productivity Commission, 2005). Secondly, there was the official government policy of populating the interior. Indeed, increasing the population in western NSW was one of the objectives of the NSW Government expenditure on irrigation (Wilkinson, 1997) (Table 1). In keeping with this policy, following World War 1, returning soldiers were settled in the area, with the numbers being boosted by new immigrants from Britain. However, peopling the interior, as government policy, was abandoned during the 1950s and 1960s (Wilkinson, 1997). Thirdly, irrigation allowed the expansion of agriculture away from riparian lands where people initially settled to more marginal lands lying further away from the river. Australia suffered from frequent severe droughts and irrigation gave more certainty of water supply to these lands than was possible with rain-fed agriculture. The certainty of water supply through irrigation resulted in more intensive agriculture production and cultivation of more profitable crops.

Much of the agricultural expansion commenced in about 1902 and continued until about 1980 with significant government funding and coordination (Wilkinson, 1997). A series of dams and weirs were built from about 1910 to about 1970. Irrigation activity invariably followed, with a significant expansion of the area under irrigation which continued up until about 1980. Expansion of agriculture and irrigation then led to a substantial growth of population within 
Table 1. Summary timeline of major policies and initiatives in the Murray-Darling Basin, State Library of South Australia (2014).

\begin{tabular}{|c|c|}
\hline $1830-1860$ & Aboriginal population along Murray-Darling devastated by European-introduced diseases including measles, smallpox and influenza. \\
\hline $1895-1902$ & Prolonged drought leads to Corowa Water Conference in 1902. \\
\hline 1901 & The Commonwealth of Australia inaugurated on 1 January. \\
\hline 1902 & $\begin{array}{l}\text { Corowa Water Conference. } \\
\text { Interstate Royal Commission on waters of River Murray for purpose of irrigation, navigation and water supply. }\end{array}$ \\
\hline 1915 & $\begin{array}{l}\text { River Murray Waters Agreement on management and sharing of waters of the River Murray signed by the governments of Australia, NSW, Victoria } \\
\text { and SA, providing for the construction of a number of storages, weirs and locks. } \\
\text { Returned Soldiers' Settlement Act. }\end{array}$ \\
\hline 1917 & $\begin{array}{l}\text { The River Murray Commission established to put the River Murray Waters Agreement into effect, particularly to ensure that each state receives its } \\
\text { agreed share of the Murray's water. }\end{array}$ \\
\hline 1922 & British Empire Settlement Act passed by Commonwealth Government to encourage British immigrants and settle rural lands in Australia. \\
\hline 1934 & $\begin{array}{l}\text { River Murray Waters Agreement amended; five barrages to be built near Murray mouth to prevent seawater entering river system during periods of } \\
\text { low river flow. }\end{array}$ \\
\hline 1946-mid-1950s & Soldier settlement schemes following World War II \\
\hline 1951 & Assisted migration arrangements with Italy, then Germany, Greece and Austria \\
\hline 1982 & $\begin{array}{l}\text { The River Murray Waters Agreement amended so the River Murray Commission can take environmental problems, including water quality issues, } \\
\text { into account. }\end{array}$ \\
\hline 1985 & $\begin{array}{l}\text { Murray-Darling Basin Ministerial Council established for providing the policy and direction to implement the Murray-Darling Basin Initiative, } \\
\text { when ministers from SA, NSW, Victoria and Commonwealth meet in Adelaide to discuss resource and environmental problems of Murray-Darling } \\
\text { Basin. }\end{array}$ \\
\hline 1987 & Murray-Darling Basin Agreement for management of water, land and natural resources across the basin. \\
\hline 1992 & New Murray-Darling Basin Agreement signed. Murray-Darling Basin Commission established to replace the former River Murray Commission. \\
\hline 1994 & CoAG (Council of Australian Governments) Water Reform Framework established. \\
\hline 1995 & $\begin{array}{l}\text { NSW Water Reform Package launched. } \\
\text { Murray-Darling Basin Ministerial Council agrees to interim cap on water diversions. } \\
\text { Federal and State governments sign Competition Policy Agreement which includes policy on water trading. }\end{array}$ \\
\hline 1996 & $\begin{array}{l}\text { Commonwealth AUD } 1.5 \text { billion Natural Heritage Trust established in response to water quality crisis. State and Territory governments to match } \\
\text { federal funding. }\end{array}$ \\
\hline 1997 & Permanent cap on the volume of water which can be diverted from Murray-Darling Basin rivers by SA, NSW and Victoria. \\
\hline 2000 & $\begin{array}{l}\text { Commonwealth Government AUD } 700 \text { million salinity package over } 7 \text { years introduced. Funding to state governments dependent on meeting federal } \\
\text { targets for land clearing and water quality. }\end{array}$ \\
\hline 2004 & $\begin{array}{l}\text { Federal and South Australian governments announce a package of measures aimed at reducing salinity, improving water quality and protecting } \\
\text { biodiversity in the Murray-Darling region under the National Action Plan for Salinity and Water Quality and National Heritage Trust }\end{array}$ \\
\hline 2007 & $\begin{array}{l}\text { AUD } 10 \text { billion basin plan - Prime Minister announces plan for Murray-Darling River system seeking support from Victoria, New South Wales, } \\
\text { Queensland, South Australian and the ACT governments. Plan requires constitutional changes. } \\
\text { Passing of the Water Act (2007) in Federal Parliament. } \\
\text { Murray-Darling Basin Authority established - The Authority was established under the Water Act (2007). }\end{array}$ \\
\hline 2010 & $\begin{array}{l}\text { The Guide to the Draft Basin Plan is released with proposed water allocation cuts of } 4000 \text { billion litres (GL). Rural communities fear their livelihoods } \\
\text { will be threatened by the proposal, and demonstrate against the plan. }\end{array}$ \\
\hline 2012 & Iurray-Darling Basin Plan. \\
\hline
\end{tabular}

the Murrumbidgee, which hit a peak in 1990 and in the case of rice production was severely influenced by the drought between 2000 and 2010. Agricultural productivity also expanded dramatically, hitting a peak around 2000. The expansion of irrigated agriculture, associated infrastructure and the size of the human population, as well as the resulting agricultural productivity and measures evidencing the environmental degradation over the last 100 years (1910-2010) are presented in summary form (Fig. 4a-h).

An indication of the nature of growth of agricultural activity can be obtained from the details presented in Figs. 1 and $4 \mathrm{a}-\mathrm{h}$. As early as 1843 much of the land along the
Murrumbidgee River had been settled by European colonists who used the water for grazing stock. Within the Murrumbidgee Basin, irrigation activity commenced in 1902 in the area around Hay (Turral et al., 2009). The overall investment of in-stream infrastructure associated with the storage and diversion of water along the Murrumbidgee River is in the order of AUD $2800 \mathrm{M}$ (State Water, 2013). Construction of the Burrunjuck Dam commenced in 1907, followed by the construction of diversion weirs and irrigation delivery canals. The Murrumbidgee Irrigation Area (MIA) commenced in 1912 and quickly expanded (incorporating the Yanco Irrigation Area, 1912; Mirrool Irrigation Area, 1924; 

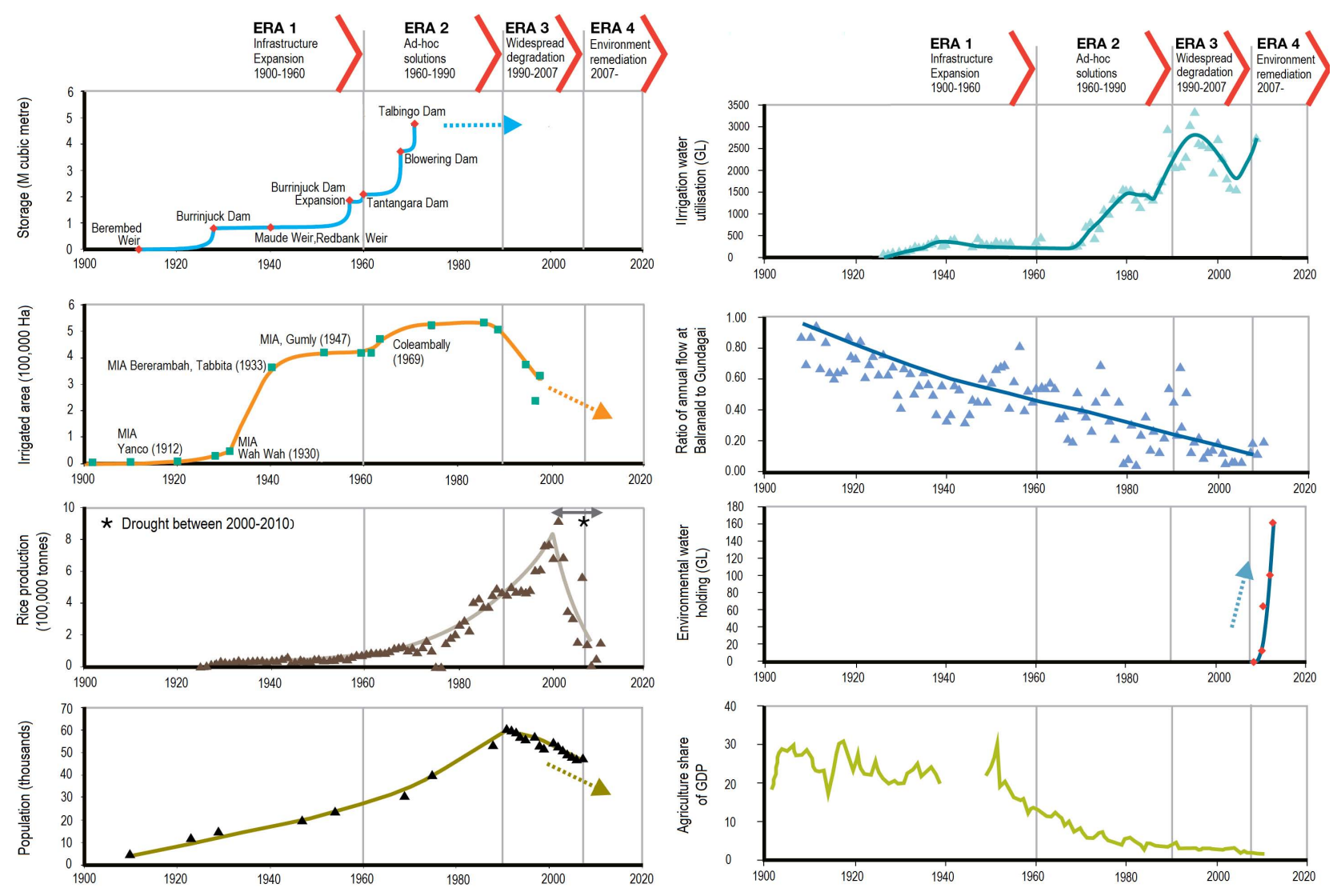

Fig. 4. (a) Development of storage in the Murrumbidgee Catchment (data sourced from NSW State Water Corporation). (b) Development of irrigation areas in the Murrumbidgee Catchment. See Fig. 1 for locations of irrigation area. Mirrool and Yanco are in the Murrumbidgee Irrigation Area. Bererembah, Tabbita, Wah Wah and Gumly are districts that adjoin Murrumbidgee Irrigation Area but not shown in Fig. 1, Lowbidgee irrigation area not included. (data sourced from ABS, 2013b). (c) Rice production in the Murrumbidgee, (data sourced from ABS, 2013b). (d) Population growth in the Murrumbidgee. Between 1900 and 1980 the population was estimated from data available in ABS year book. From 1980 onward the estimate is for the population of Murrumbidgee less the population of Canberra and Wagga Wagga, (data sourced from ABS 2013a, b). (e) Irrigation flow utilization in the Murrumbidgee Catchment, (data sourced from DWR, 1989; ABS 2013a; and State Water Corporation). (f) Ratio of annual flow in the Murrumbidgee at Balranald to the annual flow at Wagga Wagga, see Fig. 1 for locations of Balranald and Wagga, (data sourced from NSW State Water Corporation). (g) Environmental water holdings (water licenses) purchased by the Commonwealth Government and available to water sites of significant environmental value (wetlands, etc) in the Murrumbidgee Catchment, (data sourced from DSEWPC, 2013). (h) The contribution of agriculture to the Australian economy expressed as a percent of GDP (ABS, 2005).

Wah Wah Irrigation District, 1930; Benerembah Irrigation District, 1933; and Tabbita Irrigation District, 1933). Construction of more dams to increase storage capacity occurred in tandem (e.g. enlargement of Burrinjuck Dam during 19391956; Blowering Dam, 1968; Tantangara, 1960; Talbingo, 1971). The Lowbidgee Flood Control and Irrigation District (LFCID) was established in 1945. It is located at the downstream end of the Murrumbidgee River basin, but upstream of Balranald. The Lowbidgee Floodplain is the largest floodplain wetland in the Murrumbidgee Valley and is a nationally important wetland. It covers a large area (217000 ha) and is regionally significant for waterbirds, both as a drought refuge and as breeding habitat. The extent of the Lowbidgee wetlands has significantly decreased due to the construction of levee banks to establish the LFCID. The Maude and Redbank weirs facilitated the flooding of the Lowbidgee irrigation area during the winter/spring. In addition, the Coleambally Irrigation Area (CIA) area was established in 1960 (Wilkinson, 1997; Lewis, 2012).

The investment in infrastructure facilitated the growth of the whole community and the agricultural industry. Agricultural production within the Murrumbidgee included rice, wheat, soybeans, canola, citrus, vegetables and vines, as well as sheep and cattle. The first commercial crop of rice was harvested in 1924 and subsequently rice production grew rapidly (Lewis, 2012). In the early years rice was a very profitable crop compared to other grains. For this reason, the rice industry grew significantly over the next three decades, leading 


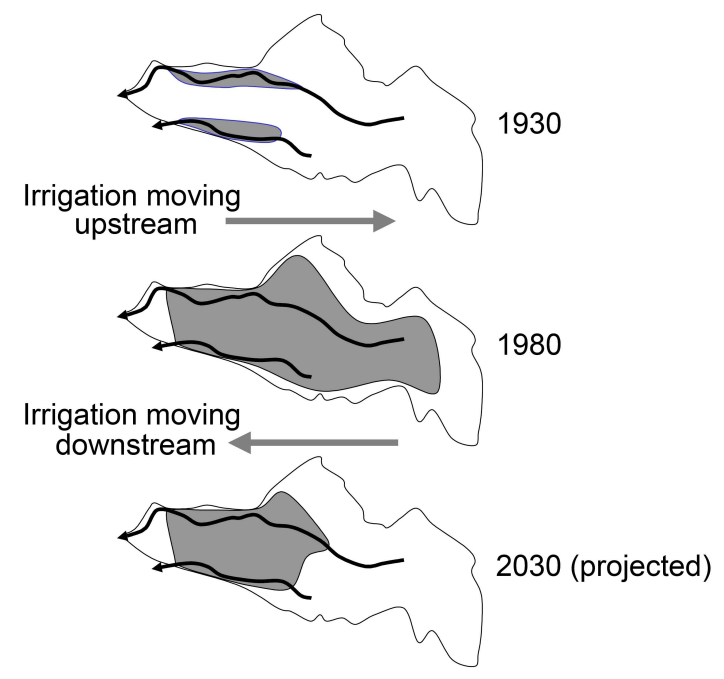

Fig. 5. Schematic of the evolution of the spatial patterns of irrigation (shaded area) in the Murrumbidgee. In the early 20th century irrigation moved upstream. Recently, the government has started buying water rights from farmers to protect the environment. Bottom panel is a projection based on cutting back irrigation upstream, reproduced with permission from Sivapalan et al. (2012).

to the construction of rice mills in the area around Leeton and Yanco, which generated greater employment. Similar growth also occurred in other sectors, such as the wine industry, with extensive support and a supply chain forming in the local community. Figure $4 \mathrm{c}$ shows the growth in rice production, which is used here as a surrogate for overall agriculture production.

However, the agricultural expansion described above did not happen uniformly across the Murrumbidgee River basin; in fact, there was a spatial aspect to it. Agriculture started in riparian areas near the outlet of the basin, and then with the onset of irrigation expanded to areas away from the river (non-riparian lands) and, aided by the construction of dams further upstream, migrated to upstream regions. This expansion also benefited from the government policy of populating the interior. Sivapalan et al. (2012) present a cartoon figure that illustrates the upward expansion of agricultural development (in terms of growth of irrigation infrastructure and area put under irrigation) within the Murrumbidgee, reproduced in Fig. 5.

\subsubsection{Era 2 (1960-1990) - Onset of environmental degradation and ad hoc solutions}

The balance in water utilization in Era 1 favoured agricultural development, with heavy government policy support and investment. Yet, there was no consideration, nor any apparent awareness of environmental requirements. This situation changed with the gradual manifestation of several environmental problems.
The first was saltwater intrusion. As water consumption in the MDB increased and flow in the rivers decreased, the intrusion of seawater was felt up to $250 \mathrm{~km}$ upstream from the mouth of the River Murray. This impacted landowners and farmers along the lower reaches of the river who strongly advocated for the construction of barrages to keep the water fresh in the lower reaches of the River Murray. Work on the barrages was completed in 1940 (Table 1).

The second problem was salinization of lands due to irrigation. As a consequence of agricultural development, deeprooted native vegetation was replaced by shallow rooted annual crops and pastures, which changed the water balance and raised groundwater levels. For example, prior to the introduction of rice, the groundwater table within the Murrumbidgee Irrigation Area (MIA) was $20 \mathrm{~m}$ below land surface. By 2001 the water table for approximately 85 percent of the MIA had risen to within $2 \mathrm{~m}$ of the surface. Rising water tables dissolved salts that were already present in the soil profile, raising them to the surface (GWG, 1996). This was compounded by the application of irrigation water, resulting in both salinization and waterlogging. The damage due to salinity was widespread, with adverse impacts on the environment of rivers and wetlands, built infrastructure, and agricultural productivity. The overall estimated annual damage due to salinity in the MDB was substantial: AUD 130 million in agricultural costs, AUD 100 million in infrastructure costs, and AUD 40 in environmental costs (ABS, 2013c).

Mitigation measures to tackle salinity were implemented in the Murray-Darling Basin. These included controlling rice production, introducing efficient irrigation practices, implementing efficient delivery and usage of town water, and expanding tree planting. Since 1988, the NSW, Victoria and South Australia governments, together with the Commonwealth Government, have funded the construction of salt interception schemes (SIS) to reduce salinity in the Murray River. The SISs are large-scale groundwater pumping and drainage projects that intercept saline groundwater flows and dispose them, usually by evaporation. In the Murray-Darling Basin, there are currently 18 operational SIS bore-fields and several under construction (MDBC, 1999).

Salinity was not the only issue to impact the region. The summer of 1991-1992 saw the occurrence (over $1000 \mathrm{~km}$ in the Murray-Darling) of one of the worst blooms of bluegreen algae recorded anywhere in the world (MDBMC, 1994). Sewage treatment plants were the cause of excess nutrients in the river and significant investment was made by the governments to upgrade wastewater treatment plants to reduce the nutrient loads. Irrigation areas were identified as having another large impact on nutrient loads and further measures were adopted to decrease nutrient runoff.

Figure 3 does recognize the initiation of infrastructure targeted towards alleviating salinity and algal blooms (e.g. barrages, SIS schemes and upgrading of sewage treatment plants). There were also attempts to institute policy changes that affect the utilization and sharing of waters, through 
extending the role of the Murray-Darling Basin Commission (MDBC; MDBC, 2011) (Table 1). These mitigation measures, especially those aimed at combating salinity, failed to reverse the degradation, as they did not address the fundamental causes of the rising water tables caused by irrigation practices. Despite the emergence of environmental problems and some efforts at remediating them, there was continued rapid growth of agriculture production and population (see Fig. 4c, d), and the balance of water utilization remained with agriculture (see Fig. 3). A holistic catchmentwide approach considering human influences and environmental requirements was not yet given proper recognition until the beginning of Era 3 .

\subsubsection{Era 3 (1990-2007) - establishment of widespread environmental degradation}

As seen in Fig. 4a and b, investment in irrigation infrastructure was largely complete by 1970, and growth of irrigation areas was largely complete by 1980 . However, irrigation water utilization continued to increase until 2000 (see Fig. 5a), although this growth was moderated somewhat by the 2000-2010 drought. The growth of water utilization was also mirrored in the growth of agricultural production (e.g. as reflected by growth of rice production, Fig. 4c). The increase in agricultural output was achieved by strong productivity growth (per hectare) and a decline in the agricultural work force. This was in part a result of a heavy reliance on mechanization, an increase in corporate farming practices and a movement of labour to other sectors of the economy. The population in the Murrumbidgee grew rapidly until 1990 but began to decline post-1990 (see Fig. 4c). The reversal is partly attributed to the changing profile of agriculture within the broader Australian economy. The agricultural share of the Australian economy began to decline from the 1950s to its current value of $4 \%$ of Australia's Gross Domestic Product (GDP), and Australia's overall reliance on agricultural exports declined to about $20 \%$ (Fig. 4h) (Productivity Commission, 2005). Economically, this contributed to a reduction of employment in the entire agricultural sector from 1980 (ABS, 2013d)

The rapid growth in water utilization for agriculture also meant a reduction of residual flow (i.e. environmental flows) in the river. This is illustrated in Fig. 4f, which shows the reduction in Murrumbidgee river flows that reaches the outlet near Balranald (see Fig. 1 for locations) over the period 1900 to 2011, expressed as a fraction of the river flow at Wagga Wagga. The flow reduction can be directly attributed to water utilization for irrigation (see Fig. 4e) sourced from the Murrumbidgee River and utilized mainly in the MIA, CIA and LFCID irrigation areas. By 2011 the fraction of flow reaching Balranald dropped to a low $10 \%$ (on average). The reduction of flows significantly reduced the frequency and duration of inundation of wetlands in the riparian areas near the river, and in this way began to impact ecosystem health
Table 2. Annual trends in waterbird abundance in three wetland systems, including the Lowbidgee (1983 to 2001) (Kingsford and Thomas, 2004).

\begin{tabular}{|c|c|c|c|}
\hline Wetland & Lowbidgee & Fivebough & Paroo Overflow \\
\hline \multicolumn{4}{|c|}{ Mean number of waterbird species between: } \\
\hline $1983-1986$ & 34 & 13 & 20 \\
\hline 1998-2001 & $27(-21 \%)^{*}$ & $12(-8 \%)^{*}$ & $23(15 \%)^{*}$ \\
\hline \multicolumn{4}{|c|}{ Mean population of waterbird species between: } \\
\hline 1983-1986 & 139939 & 6844 & 14224 \\
\hline $1998-2001$ & $14170(-90 \%)^{*}$ & $911(-87 \%)^{*}$ & $18616(31 \%)^{*}$ \\
\hline
\end{tabular}

of these riparian environments, including the fauna and flora that depended on these wetlands.

For example, Fivebough Swamp and Tuckerbil Swamp are Ramsar-designated wetlands. Both are located near Leeton, within the MIA (Fig. 1). Other significant wetlands in the Murrumbidgee are the Lowbidgee Floodplain, located within the LFCID, and the mid-Murrumbidgee Wetlands, which are riparian wetlands between Wagga Wagga and Carrathool, each of which cover significant areas. Changes to the wetland areas within the Lowbidgee were assessed by Kingsford and Thomas (2004), who estimated that between 1902 and 1998 some 232276 ha of wetlands (out of the 303781 ha that existed in 1902) had been lost or degraded. This has been due to flow regime changes in the regulated Murrumbidgee River, the construction of levee banks to control floodwaters, and the conversion of wetland floodplains into irrigated cropland.

Trend analyses of the number of species of different waterbird groups and their overall abundance were carried out using annual aerial surveys between 1983 and 2000 across the Lowbidgee floodplain, Fivebough Swamp, and the Paroo overflow lakes (Table 2, taken from Kingsford and Porter, 1994). Paroo lakes are located in the north-west of NSW in an area relatively free from agricultural development. This analysis showed a significant reduction in waterbirds in parts of the Murrumbidgee that experienced significant loss or degradation of wetlands, relative to those that did not (e.g. Paroo lakes). Similar to waterbirds, the native fish community within the Murrumbidgee Basin has also been severely depleted. A survey by Gillian (2005) showed that 8 of the 21 native fish species were either locally extinct or survive at very low abundances. In addition to the loss of native species, a large number of invasive fish species have become dominant, both in terms of number $(71 \%)$ and biomass $(90 \%)$.

With the realization of the severity of the environmental degradation, which was proceeding unabated, several measures were instituted to control the environmental degradation. These covered the entire spectrum of new infrastructure, policy changes and also economic measures. For example, no new licenses for water extraction were issued after 1986, even though the proportion of flow allocated to 
irrigation continued to expand on the basis of existing licenses (Turral et al., 2009). In 1993, the MDBC introduced a temporary cap on further expansion of water extraction, which was made permanent in 1997 (MDBMC, 2000) (Table 1). Another initiative of the NSW state government was to construct fishways which would allow fish to pass barriers within the rivers, which was now required of all significant upgrade or renewal works undertaken in the rivers used for irrigation. As a result, since 1985, 27 fishways have been built. As the major irrigation structures in the Murrumbidgee River are upgraded, the estimated investment in the construction of fish passage is estimated to be AUD 50 to AUD 60 million over the next 20 to 30 years (State Water, 2013).

The most important changes happened in the policy and economic domains. The Council of Australian Governments (COAG, 1994) in 1994 developed a Water Reform Package which, for the first time, recognised that the environment was a legitimate user of water in its own right (Table 1) (Arthington and Pusey, 2003; Schofield et al., 2003; COAG, 1994). The NSW Government in 1997 followed with reforms culminating in the Water Management Act (WMA) of 2000, a key legislation underpinning the protection of environmental flow. Under the WMA Act, Water Sharing Plans (WSPs) were developed that sought a balance between requirements of industry, agriculture, domestic use and the environment. Other key reforms introduced as part of these legislations include the separation of water titles from land, adoption of water trading arrangements and establishment of a water market, full cost recovery and removal of cross subsidies in the supply of water, and importantly, institutional arrangements to support these reforms (Schofield et al., 2003).

\subsubsection{Era 4 (2007-present) - remediation and emergence of the environmental customer}

In spite of the increasing recognition of the water needs of the environment and several mitigation measures instituted during Era 3, these did little to reverse environmental degradation. Community concerns consequently grew at the failure to develop viable solutions, notwithstanding the measures developed in Era 3. These concerns were highlighted strongly by the "green" lobby, which has grown in influence since the 1990s. This, combined with a strong fiscal economic position experienced in Australia (owing to the mining "boom"), and the diminishing role of agriculture as a contributor in the Australian economy (Fig. 4h), changed community attitudes towards the environment and strengthened the Commonwealth Government's hand.

In 2007 the Commonwealth Government announced a AUD 10 billion national water reform package (Table 1) (later increased to AUD 12.9 billion, Turral et al., 2009). It called for the states covering the MDB to transfer their constitutional powers over water management to the Commonwealth so that comprehensive MDB-wide reforms could be introduced. The main thrust of the AUD A12.9 billion plan was to reduce the allocated water volume to agriculture in return for system and on-farm investments in water conservation. This has also added impetus to the need to account for surface water and groundwater flows, and to monitor and control the capture of runoff on farms. In all states, the ability to capture runoff in farm dams was restricted through new licensing requirements. The 2007 Water Act created an independent Murray-Darling Basin Authority (MDBA). It began to set sustainable diversion limits that can be taken from surface water and groundwater systems within the MDB. It also included an environmental watering plan to optimize environmental outcomes. The Act further established an Environmental Water Holder to protect and restore environmental assets within the MDB (Fig. 4g).

As part of the Commonwealth Government's AUD 12.9 billion program, significant projects within the Murrumbidgee River are now being implemented. These are aimed at upgrading infrastructure and operational processes. They include a suite of infrastructure works designed to minimize in-stream river losses, either through improved metering of customers or reducing water flowing to places where it is not required. As part of these projects more detailed information on the cost of delivering water (in terms of evaporation and infiltration losses) to different parts of the catchment are being assembled. This will allow further policy development, such as purchasing water licenses for the environment from areas that are more costly to deliver water to. Differential water pricing that will allow further efficiencies and transparency in the use of water is envisaged. Other projects include modification of bridges to allow the passage of water to flood wetlands, and weirs to divert water to wetlands.

Several other mitigation measures that the government has introduced are intended to reverse environmental degradation by reducing water allocation to agriculture in favour of flows to the environment. These are in four main areas: new policies (i.e. legislation to impose a solution, creation of the MDBA and the office of the Environmental Water Holder), new economic measures (e.g. massive funding, buying back of water licences, water trading), new technologies (e.g. incentives to change the type of crops grown, efficient farm irrigation), and new infrastructure.

The consequence of all of these actions was that irrigation infrastructure (in terms of area put under irrigation and associated infrastructure) that was moving upstream for the first 75 years of agricultural development is now expected to move back downstream (Sivapalan et al., 2012). An example of this is that over the 2001-2009 drought period rice growers were able to make more money with less risk by selling their water in the water trading market rather than by growing rice. The sale of water by rice growers helped downstream horticulturalists to keep their plantings alive, and new horticulturalists moved in to grow highly profitable produce in areas downstream of the Murrumbidgee, e.g. Sunraysia and Goulburn regions of the state of Victoria and Riverland in the state of South Australia (NWI, 2011, 2010). 
The mix of solutions imposed by the government during Era 4 was in part arbitrated by interactions and feedback between the affected local community and local stakeholders, and the increasing political influence of environmentally aligned political parties and lobby groups. In effect, the government was responding to changing community attitudes, even though these normally tend to lag well behind the system changes. In any case, the net result is that the pendulum has now materially "swung" back to the environment. As a result of the massive funding directed at environmental remediation and enhancement, the population within the Murrumbidgee is expected to decline further, and agricultural activity is expected to follow.

\section{Discussion: lessons learned - need for new socio-hydrologic prediction frameworks}

As we survey what transpired over the past century, it is notable that in the short term (i.e. during an individual Era), these involved the implementation of IWRM, ostensibly using the best tools available, including hydrologic prediction tools. Here, scenario analysis is used to assess the impact of prescribed changes, including management plans, and typically feedbacks, co-evolution and non-stationarity in system behaviour are not incorporated (Montanari et al., 2013). However, in the long term, the environmental problems only got worse and reached a crisis situation by the 1990s. This was predominantly due to a poor understanding or lack of awareness of environmental impacts. Economically, we might assert that the environment was undervalued. By the time the environment began to be valued (owing to scarcity of water for the environment, and resultant threat of loss in flora and fauna), there were no analysis or prediction frameworks that could account for environmental feedbacks that impacted on human behaviour in respect of water.

Above all, the Murrumbidgee case study illustrates what could happen when the underlying human preferences, i.e. what humans value, change over time and prediction frameworks fail to stay abreast of these altered assumptions. The values and norms relating to water and the environment changed over the past century due to several factors: the realization of the damage to the environment is the first. Another is the growth of the economy overall, and the diminution of agriculture and food exports as a fraction of the national and regional economy (Fig. 4h). Thirdly, tied to these, was the general growth of environmental awareness and growth of the "green" lobby. All of these together created the conditions for decisions to reallocate water to the environment. In other words, changes in norms and values were themselves a result of human-water system feedbacks.

The net result of all this is that the human-water system in the Murrumbidgee has witnessed interesting longterm stakeholder interaction dynamics that could not have been perceived a century, or even 50 years ago. Temporally, this manifested as the growth of irrigation and its eventual turnaround (as shown in Figs. 3 and $4 \mathrm{a}-\mathrm{h}$ ): irrigation here stands variously for area under irrigation, amount of water utilized in irrigation, agricultural productivity, size of human population, and size of irrigation infrastructure. There is also a spatial aspect. Figure 5, reproduced from Sivapalan et al. (2012), indicates schematically that the growth of irrigation involved the upstream migration of indicators of irrigation. The eventual turn-around in irrigation then involved a downstream migration of the same. These complex dynamics, which involve pendulum swings, were the result of the two-way feedbacks between the hydrologic and human systems; in effect they can be considered as "emergent" dynamics. These emergent dynamics, in this case the pendulum swing, could not have been predicted using traditional hydrologic prediction frameworks.

The pendulum swing has proved costly to the environment, local communities and government. Yet, there is no guarantee that the imposed solutions will fix the problem indefinitely. Imposed solutions by governments on complex inter-dependent systems such as this are seldom successful and the outcomes which manifest many years later seldom align with the original objectives or intentions. Indeed, it is not absolutely clear what the situation will be in another 50 years for the people, and for the environment. It also raises several related questions: Could the situation have been avoided in the first place? What would happen if the government had not intervened? Are there other plausible solutions? Now that the government has intervened, what does the future hold for the people and the environment?

The Murrumbidgee experience teaches us that simplistic hydrologic predictive frameworks that link demand to population growth or economic growth will not be adequate in the long-term. Likewise, traditional economic frameworks that allocate water between multiple human users are also not adequate. These frameworks are elements of the integrated water resource management (IWRM) approach, which has as its focus controlling or managing the water system to reach desired outcomes for society and the environment. The Murrumbidgee experience clearly demonstrates the weakness of the IWRM approach for sustainable water resource management over decadal to century timescales, due to the fact that it cannot account for the bi-directional feedbacks between hydrological and human systems that have been responsible for much of the complex, emergent dynamics witnessed in the Murrumbidgee.

Instead of the costly pendulum swing experienced in the Murrumbidgee, more incremental shifts may be possible with a properly developed and coupled socio-hydrologic model that includes the bi-directional feedbacks between human and water systems. Such models can track the coevolution of the physical (hydrological), human (social systems, infrastructure, agricultural), and environmental (biogeochemical, ecological) sub-systems in response to external drivers (i.e. climate variables, market conditions, food 


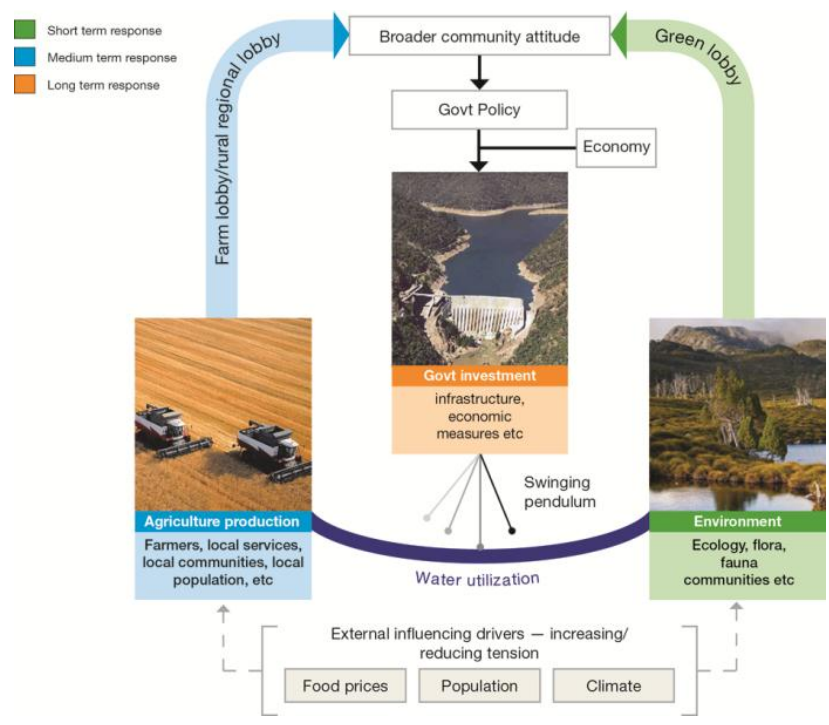

Fig. 6. Framework for socio-hydrologic modelling: interactions and feedbacks between human and environmental systems leading to new (whole system) dynamics.

prices), and the demand for water and food (i.e. governed by human population). Better still, they might pave the way for self-organized solutions (Ostrom, 2009) that provide the resource productivity that humans aspire to that nevertheless are not detrimental to the health of ecosystems.

Figure 6, a distillation of Fig. 2, provides the essence of a new conceptual framework of a socio-hydrology model applicable to the Murrumbidgee River basin that naturally arose from the historical (including quantitative) analysis of what happened. The development of such coupled models of socio-hydrological systems requires the formulation of inter-connected sub-systems that co-evolve, albeit at different rates. Quantitative analyses of the drivers of the sociohydrological system and trajectories of their co-evolution can provide insights and parameterizations necessary to build such coupled models, especially relating to key feedbacks that influence possible trajectories of system co-evolution. Some aspects of natural systems, such as the surface hydrologic system, respond promptly to external changes to reach new equilibrium levels. This can be deemed as fast dynamics (Fig. 6). On the other hand, the evolution of human systems such as infrastructure development is more deliberate and occurs over a longer period of time. For example, irrigation infrastructure within the Murrumbidgee developed over a period of 70 years, governed by macro-economic conditions and political imperatives. The growth and dynamics of human populations in agricultural production follow the growth and dynamics of irrigated infrastructure, but with a multi-year delay. On the other hand, decisions humans make about the land area to be put to irrigation and the types of crops grown occur in the medium term, in response to medium-term variability in external drivers such as climate and commodity prices. Insights into these dynamics can be gained through careful analysis of available data, such as those presented in Figs. 3 to $4 \mathrm{a}-\mathrm{h}$. These insights have helped to develop a conceptual model of the Murrumbidgee sociohydrologic system (Fig. 6), as a distilled version of the complex picture presented in Fig. 2. This together with a more generalized version (Ostrom, 2009) can form the basis of simple, quasi-distributed numerical models of the coupled human-nature system, which remains a work in progress (van Emmerik et al., 2014).

However, the trajectory of co-evolution of coupled sociohydrologic systems presented here is not unique to Murrumbidgee. Similar cases of peak anthropogenic water or "water reallocation to nature" have been reported throughout the developed world, such as in the Rio Grande, Edwards Aquifer. Similar dynamics are also being reported in western China in the Tarim Basin in Xinjiang Province (Liu et al., 2013). In the wider environmental literature the Ushaped relationship between GDP and environmental degradation shown in Fig. 4 has been referred to as the "Environmental Kuznets Curve" (EKC), suggesting the existence of a common organizing principle that might underpin a new generation of coupled models (Stern, 2004; Suri and Chapman, 1998). The EKC describes the gradual shift towards the recognition and treatment of sustained environmental degradation and represents the increasingly egalitarian concerns of a society that is progressively more affluent and thus concerned with broader issues than simply those that are economic. The applicability of EKC, or other different organizing principles that underpin the pendulum swings, as highlighted in the case of the Murrumbidgee Basin is worthy of further investigation, but is beyond the scope of this paper.

The socio-hydrologic prediction frameworks such as the one presented above can also help interpret similarity and differences in behaviour between different places, and to interpret them in terms of climatic, socio-economic and socio-cultural factors. The development of coupled models of socio-hydrological systems that may be applied everywhere requires a more generalized framework that is widely applicable through generalizing the drivers and the resulting interactions and feedbacks in a manner that has wider applicability across climatic and socio-economic gradients (Ostrom, 2009).

\section{Conclusions}

The complex dynamics witnessed in the Murrumbidgee River basin paper illustrates the challenge of predicting longterm hydrologic trajectories in coupled human-water systems. In particular, it shows that simplistic relationships such as between GDP and water use, or extrapolation of past hydrologic trends of the future, do not adequately capture the evolution of water systems. The Murrumbidgee case study suggests that the hydrologic response in respect of relative 
allocation to humans and the environment is influenced by the underlying socio-economic and institutional structures, which are themselves shaped by societal values - and these values are fluid and ever-changing, thus requiring constant re-visiting of predictive model assumptions.

This paper has explored the history of water management in the Murrumbidgee River basin in eastern Australia, with a focus on efforts to mediate the competition for water between irrigated agriculture and the health of the riparian environment. The history of water management within the Murrumbidgee River basin over the past 100 years was divided into four eras. In Era 1 (1910-1960) the focus was exclusively on development of agriculture with no awareness of, or attention paid to, environmental issues. Era 2 (1960-1990) was the period which saw the onset of environmental problems in the form of salinity. While the human response to salinity was immediate in terms of remedial infrastructure, it did not address the fundamental causes and therefore the problems persisted. Era 3 saw further widespread environmental degradation, with several mitigation measures implemented in the form of policy changes, infrastructure development, and the use of economic measures. These initiatives failed to reverse environmental degradation. Finally, Era 4 saw the implementation of a mix of solutions, some drastic, imposed by government to reverse environmental degradation: these seem to have set in motion an environmental remediation and emergence of the "environmental customer".

The history of conventional water management has given rise to complex emergent dynamics, involving a pendulum swing that expresses a dramatic change in emphasis from agricultural development and food production in the first 50 years, which contributed to degradation of the environment, to sustained efforts to mitigate and reverse environmental degradation and restore ecosystem health. The pendulum swing is a result of several environmental and socio-economic factors: evidence of worsening environmental degradation, evolution of societal norms and values relating to the environment, and favourable economic conditions that emboldened the government to act decisively. Nevertheless, the pendulum swing has been costly to the environment, local communities and the government, and only arose because hydrologic prediction frameworks that supported conventional integrated water management did not include bidirectional feedbacks between the human and hydrological systems. The availability and use of such coupled models may have prevented widespread environmental degradation.

Although this case study describes the particulars of the Murrumbidgee case study in great detail, the circumstances are not unique. Rather, it typifies a trajectory that has been observed in other cases. Several authors have reported the reallocation of water from anthropogenic to ecological uses. Indeed, improved environmental outcomes as societies become wealthier and more focused on environmental concerns has been described via the Environmental Kuznets Curve. This therefore suggests that though individual water systems in different settings are extremely complex and unique, there is hope that general organizing principles may still be found for future research to consider.

Trajectories of co-evolution of coupled humanenvironment systems are governed by the nature of the interactions and feedback between the decisions of humans to utilize water resources to derive socio-economic benefits and by the adaptive capacity of the environmental systems. Clearly, to avoid costly pendulum swings, or to obtain more realistic predictions of the future, this paper argues for the development of coupled socio-hydrological models with explicit inclusion of bi-directional feedbacks and the possibility of accommodating evolving norms and values relating to water and the environment. These models have the potential to help plot a path explaining the evolution of coupled human-water systems under various scenarios. This will provide guidance for sustainable development, and the means to avoid costly pendulum swings as observed in the Murrumbidgee. They also provide the foundation for comparative studies across gradients of climatic, socio-economic and socio-cultural conditions.

Acknowledgements. The work on this paper has been supported in part by a supplementary grant from the US National Science Foundation to the Hydrologic Synthesis project "Water Cycle Dynamics in a Changing Environment: Advancing Hydrologic Science through Synthesis" (EAR-0636043, PI: M. Sivapalan). The authors thank Veena Srinivasan for providing very insightful comments, which helped to substantially improve the paper. The authors also thank Adrian Williams, Gurmeet Singh and Daniel Masters for providing data used in this study and for helpful discussion.

Edited by: T. J. Troy

\section{References}

ABS: 100 years of change in Australian industry. 1301.0 Year Book Australia, 2005, Australian Bureau of Statistics, available at: http://www.abs.gov.au/AUSSTATS/abs@.nsf/ lookup/1301.0feature+article212005, (last access: May 2013), 2005.

ABS: Australian Bureau of Statistics, available at: http://www.abs. gov.au/ (last access: May 2013), 2013a.

ABS: Australian Yearbook, Australian Bureau of Statistics, available at: http://www.abs.gov.au/AUSSTATS/abs@.nsf (last access: May 2013), 2013b.

ABS: Australia's Environment: Issues and Trends, (4613.0) 2007, Australian Bureau of Statistics, available at: http://www.abs.gov.au/AUSSTATS/abs@.nsf/ (last access: January 2014), 2013c.

ABS: Labour Force Australia Detailed Quarterly- Employed Persons By Industry Subdivision Sex-Employed Total- AgriculturePersons, Australian Bureau of Statistics ABS-6291.0.55.003, Canberra Australia, 2013d. 
Arthington, A. H. and Pusey, B. J.: Flow restoration and protection in Australian rivers, River Res. Applic., 19, 377-395, 2003.

Cai, X., McKinney, D. C., and Lasdon L. S.: A framework for sustainability analysis in water resources management and application to the Syr Darya Basin, Water Resour. Res., 38, 21-1-21-14, 2002.

COAG: Council of Australian Governments water reform framework, Canberra, Australia: Council of Australian Governments Australian Government Publishing Service, 1994.

DSEWPC: Department of Sustainability, Environment, Water, Population and Communities Annual Reports, available at: http://www.environment.gov.au/about/publications/ annual-report/index.html (last access: May 2013), 2013.

DWR: Water distribution operations in irrigation areas and districts of NSW, New South Wales Department of Water Resources, Gutteridge, Haskins \& Davey, Sydney, 1989.

Gleick, P. H. and Palaniappan, M.: Peak water limits to freshwater withdrawal and use, Proc. Natl. Acad. Sci., 107, 11155-11162, 2010.

Gilligan, D.: Fish communities of the Murrumbidgee catchment: Status and trends, NSW Department of Primary Industries Fisheries Final Report Series No. 75, ISSN 1449-9967, 2005.

GWG: Murray-Darling Basin Status of Groundwater 1992, Groundwater Working Group Technical Report No. 2. Murray-Darling Basin Commission, Canberra, 1996.

Humphries, P.: Historical Indigenous use of aquatic resources in Australia's Murray-Darling Basin, and its implications for river management, Ecol. Manage. Restor., 8, 106-113, 2007.

Kingsford, R. T. and Porter, J. L.: Waterbirds on an adjacent freshwater lake and salt lake in arid Australia, Biolog. Conserv., 69, 219-228, 1994.

Kingsford, R. T. and Thomas, R. F.: Destruction of Wetlands and Waterbird Populations by Dams and Irrigation on the Murrumbidgee River, in Arid Australia, Environ. Manage., 34, 383396, 2004.

Lewis, G.: The Growers' Paddy - Land, Water and Co-operation in the Australian Rice Industry to the 1990s, available at: http://sydney.edu.au/business/_data/assets/pdf_file/0008/ 155969/Lewis-GrowersPaddy-2012.pdf (last access: March 2013), 2012.

Liu, Y., Tian, F., Hu, H., and Sivapalan, M.: Socio-hydrologic perspectives of the co-evolution of humans and water in the Tarim River Basin, Western China: the Taiji-Tire Model, Hydrol. Earth Syst. Sci. Discuss., 10, 12753-12792, doi:10.5194/hessd10-12753-2013, 2013.

MDBA: Guide to the proposed Basin Plan: overview, MurrayDarling Basin Authority, Canberra, MDBA publication no. 60/10, ISBN (print) 978-1-921557-72-9, 2010.

MDBC: Salinity and Drainage Strategy - Ten Years On 1999, Murray-Darling Basin Commission, Canberra, ACT, 1999.

MDBC: A Brief History of the Murray-Darling Basin Agreement, Murray-Darling Basin Commission, Canberra, Australia, available at: http://www2.mdbc.gov.au/about/history_mdbc.html (last access: December 2012), 2011.

MDBMC: The Algal Management Strategy for the Murray-Darling Basin: a component of the natural resources management strategy, Murray-Darling Basin Ministerial Council, Canberra, 1994.
MDBMC: A review of the operation of the cap: Overview report of the Murray Darling Basin Commission Ministerial Council, Murray-Darling Basin Ministerial Council, Canberra, 2000.

Montanari, A. Young, G., Savenije, H. H. G., Hughes, D., Wagener, T., Ren, L. L., Koutsoyiannis, D., Cudennec, C., Toth, E., Grimaldi, S., Blöschl, G., Sivapalan, M., Beven, K., Gupta, H., Hipsey, M., Schaefli, B., Arheimer, B., Boegh, E., Schymanski, S. J., Di Baldassarre, G., Yu, B., Hubert, P., Huang, Y., Schumann, A., Post, D. A., Srinivasan, V., Harman, C., Thompson, S., Rogger, M., Viglione, A., McMillan, H., Characklis, G., Pang, Z., and Belyaev, V.: Panta Rhei - Everything Flows: Change in hydrology and society - The IAHS Scientific Decade 2013-2022, Hydrol. Sci. J., 58, 1256-1275, doi:10.1080/02626667.2013.809088, 2013.

Murrumbidgee CMA: Murrumbidgee catchment action plan, Wagga Wagga, NSW: Murrumbidgee Catchment Management Authority, 2006.

Murrumbidgee CMA: Our Catchment, Murrumbidgee Catchment: Rich and Diverse, available at: http://www.murrumbidgee.cma. nsw.gov.au/about/catchment.aspx ?print=1 (last access: December 2012), 2012.

NWI: The impacts of water trading in the southern Murray-Darling Basin: an economic, social and environmental assessment, National Water Commission, Canberra, Australia, ISBN 978-1921107-98-6, 2010.

NWI: Water trading in the rice industry, National Water Commission, Canberra, Australia, 2011.

Ostrom, E.: A General Framework for Analyzing Sustainability of Social-Ecological Systems, Science, 325, 419-422, 2009.

Productivity Commission: Trends in Australian Agriculture, Research Paper, Canberra, Australia, 2005.

Richter, B. D.: Tapped out: how can cities secure their water future?, Water Pol., 15, 335-363, 2013.

Roderick, M. L.: Introduction to special section on Water Resources in the Murray-Darling Basin: Past, present, and future, Water Resour. Res., 47, W00G01, doi:10.1029/2011WR010991, 2011.

Schofield, B., Burt, A., and Connell, D.: Environmental water allocation: Principles, policies and practices, Canberra, Australia: Land and Water Australia, 2003.

Scholz, J. T. and Stiftel, B.: Adaptive Governance and Water Conflict: New Institutions for Collaborative Planning, Resources for the Future, 2005.

Sivapalan, M.: Predictions under Change (PUC): Water, Earth and Biota in the Anthropocene, Research Report. Center for Water as a Complex Ecosystem, University of Illinois at UrbanaChampaign, available at: http://www.tandfonline.com/doi/pdf/ 10.1080/02626667.2011.580747, 2011.

Sivapalan, M., Savenije, H. H. G., and Blöschl, G.: Sociohydrology: A new science of people and water, Hydrol. Process., 26, 1270-1276, 2012.

Srinivasan, V., Lambin, E. F., Gorelick, S. M., Thompson, B. H., and Rozelle, S.: The nature and causes of the global water crisis: Syndromes from a meta-analysis of coupled human-water studies, Water Resour. Res., 48, W10516, doi:10.1029/2011WR011087, 2012.

Suri, V. and Chapman, D.: Economic growth, trade and energy: implications for the environmental Kuznets curve, Ecol. Econ., 25, 195-208, 1998. 
State Library of South Australia: River Murray timeline 1800present, available at: http://www.slsa.sa.gov.au/murray/timeline. htm (last access: January 2014), 2014.

Stern, D. I.: The rise and fall of the Environmental Kuznets Curve, World Develop., 32, 1419-1439, doi:10.1016/j.worlddev.2004.03.004, 2004.

Turral, T., Connell, D., and McKay, J.: The Drama of Restraining Water Use, Chap. 12, in: River Basin Trajectories: Societies, Environments and Development, edited by: Molle, F. and Wester, P., CAB International 2009, 2009. van Emmerik, T., Zheng, Li, Sivapalan, M., Savenije, H. H. G., Kandasamy, J., and Chanan, A.: Socio-hydrologic modeling to understand and mediate the competition for water between humans and ecosystems: Murrumbidgee River Basin, Australia, Hydrol. Earth Syst. Sci., this issue, submitted, 2014.

Wilkinson, J.: Water for Rural Production in NSW: Grand Designs and Changing Realities, NSW Parliamentary Library Research Service, Briefing Paper No 26/97, ISBN 0731316045, 1997. 